\title{
Buckling of the Ligamentum Flavum as a Rare Complication of Anterior Cervical Corpectomy and Fusion: A Case Report
}

\section{Flambagem do ligamento amarelo como uma rara complicação da corpectomia cervical anterior e fusão: um relato de caso}

\author{
Omar F. Jbarah ${ }^{10}$ Sultan Jarrar ${ }^{10}$ Hassan M. Abushukair ${ }^{20}$ Sebawe S. Syaj ${ }^{20}$ \\ ${ }^{1}$ Division of Neurosurgery, Department of Neuroscience, King \\ Abdullah University Hospital, Faculty of Medicine, Jordan University \\ of Science and Technology, Irbid, Jordan \\ ${ }^{2}$ Faculty of Medicine, Jordan University of Science and Technology, \\ Irbid, Jordan \\ Address for correspondence Omar F. Jbarah, MD, Division of \\ Neurosurgery, Department of Neuroscience, King Abdullah University \\ Hospital, Faculty of Medicine, Jordan University of Science and \\ Technology., PO Box 3030, Irbid 22110, Jordan \\ (e-mail: O.jbarah@gmail.com).
}

Arq Bras Neurocir 2021;40(4):e399-e403.

\begin{abstract}
Keywords

- anterior cervical discectomy

- corpectomy

- ligamentum flavum

- cervical spondylotic myelopathy

- case report

Introduction and Importance Neurological deterioration due to buckling of the ligamentum flavum (LF) is an uncommon complication after anterior cervical corpectomy or discectomy with fusion.

Case Presentation In this report, we present the case of a 66-year-old male who underwent anterior cervical partial corpectomy of $\mathrm{C} 5$ and discectomy of prolapsed C5C6 with fusion. Postsurgery, the patient displayed signs of neurological deterioration. Upon immediate cervical magnetic resonance imaging (MRI), posterior canal stenosis and severe compression with cord signal due to LF buckling were detected. A posterior laminectomy procedure and canal decompression at the C5-C6 level with bone fusion were performed.

Clinical Discussion Patient presented with walking difficulty, then walking disability, followed by bilateral upper and lower limb paresthesia with burning sensation. Examination showed $4 / 5$ muscle strength in both handgrips. Further investigation showed brisk deep tendon reflexes, positive Hoffman sign unilaterally, equivocal Babinski sign, and progressive quadriparesis. Magnetic resonance imaging showed mild and diffuse building of some cervical discs, with spinal cord progression. We performed an anterior cervical corpectomy and fusion (ACCF) and anterior cervical discectomy and fusion (ACDF); a titanium mesh with plates and screws was used for fusion, with removal of a calcified and herniated subligamentous disc. Postoperatively, upper and lower limb strength deteriorated; immediate cervical and thoracic MRI showed LF buckling, which caused canal stenosis and severe compression. Urgent
\end{abstract}

received

July 16, 2021

accepted

July 30, 2021
DOI https://doi.org/

10.1055/s-0041-1739276. ISSN 0103-5355.

\footnotetext{
(c) 2021. Sociedade Brasileira de Neurocirurgia. All rights reserved. This is an open access article published by Thieme under the terms of the Creative Commons Attribution-NonDerivative-NonCommercial-License, permitting copying and reproduction so long as the original work is given appropriate credit. Contents may not be used for commercial purposes, or adapted, remixed, transformed or built upon. (https://creativecommons.org/ licenses/by-nc-nd/4.0/)

Thieme Revinter Publicações Ltda., Rua do Matoso 170, Rio de Janeiro, RJ, CEP 20270-135, Brazil
} 


\section{Resumo}

\author{
Palavras-chave \\ - discectomia cervical \\ anterior \\ - corpectomia \\ - ligamento amarelo \\ - mielopatia \\ espondilótica cervical \\ - relato de caso
}

posterior laminectomy and canal decompression with bone fusion was scheduled on the same day. The patient underwent physiotherapy and regained upper and lower limb strength and his ability to walk.

Conclusion This indicates the possibility of neurological deterioration as a result of LF buckling, which may be a result of LF thickening accompanied by hyperextension in the cervical region. In this regard, immediate imaging following signs of neurological complications after anterior cervical corpectomy or discectomy warrants early detection, which results in a better prognosis.

Introdução e importância Deterioração neurológica devido à flambagem do ligamento amarelo (LA) é uma complicação incomum após corpectomia cervical anterior ou discectomia com fusão.

Apresentação do caso Neste relato, apresentamos o caso de um homem de 66 anos que foi submetido a corpectomia cervical anterior parcial de $C 5$ e discectomia de $C 5$ prolapso C6 com fusão. Após a cirurgia, o paciente apresentou sinais de deterioração neurológica. Após a ressonância magnética cervical imediata, estenose do canal posterior e compressão severa com sinal de corda devido a flambagem LF foram detectadas. Um procedimento de aminectomia posterior e descompressão do canal no nível C5-C6 com fusão óssea foram realizados.

Discussão clínica O paciente apresentou dificuldade de locomoção e, em seguida, deficiência para locomoção, seguida de parestesia bilateral dos membros superiores e inferiores com sensação de queimação. 0 exame mostrou $4 / 5$ de força muscular em ambas as empunhaduras. Investigação aprofundada mostrou reflexos tendinosos profundos e vivos, sinal de Hoffman positivo unilateralmente, ambíguo sinal de Babinski e quadriparesia progressiva. A ressonância magnética mostrou construção leve e difusa de alguns discos cervicais, com progressão da medula espinhal. Nós realizamos uma corpectomia cervical anterior e fusão e discectomia cervical anterior e fusão; uma malha de titânio com placas e parafusos foi usada para fusão, com remoção de disco subligamentar calcificado e herniado. No pós-operatório, resistência dos membros superiores e inferiores se mostrou deteriorada; ressonância magnética cervical e torácica imediata mostrou flambagem de LF, que causou estenose do canal e compressão severa. Urgente laminectomia posterior e descompressão do canal com fusão óssea foram agendadas em o mesmo dia. O paciente foi submetido a fisioterapia e recuperou força dos membros superiores e inferiores e sua capacidade de andar.

\section{Introduction}

Cervical spondylotic myelopathy (CSM) is one of the most common forms of spinal injury in adults, especially in patients above the age of 55 . Cervical spondylosis is characterized by degenerative changes of the spine, which cause CSM due to compression of the spine. ${ }^{1}$ Although $85 \%$ of adults older than 60 present radiological evidence of CSM with risk of progression, only $10 \%$ of patients above 55 suffer from clinical symptoms of CSM. ${ }^{2}$

In this regard, anterior cervical corpectomy and fusion (ACCF) and anterior cervical discectomy and fusion (ACDF) have been the most frequently used procedures for the management of both single- and multi-level CSM. Commonly presented complications after ACCF include dysphagia, pneumonia, need for blood transfusion, and formation of hematoma/seroma. ${ }^{3,4}$ Yet, buckling of the ligamentum flavum (LF) has been rarely reported as a postsurgical complication of anterior cervical corpectomy or discectomy.

In this report, we present the case of a patient who experienced lower limb weakness following $\mathrm{C} 5$ partial corpectomy with C5-C6 discectomy and in whom laminectomy was performed to relieve canal compression.

\section{Case Presentation}

A 66-year-old male experienced walking difficulty for around 30 days, in which the patient could only walk with assistance. Upon the end of the $4^{\text {th }}$ week of this complaint, his condition eventually exacerbated to complete walking disability during the following week. During this 5-weeks period, he experienced an increasing bilateral upper and 
lower limb paresthesia and burning sensation, especially over his feet (started from elbows to fingertips and from upper thighs to toes). The patient had urine and stool incontinence, and he reported having erectile dysfunction 2 years ago. The patient was diabetic, obese, hypertensive, and hypercholesteremic.

Upon neurological examination, muscle strength was $5 / 5$ in all extremities except in both the upper right and left handgrips, where it was $4 / 5$. The patient had brisk deep tendon reflexes all over, positive Hoffman sign on the left side, equivocal Babinski sign, and progressive quadriparesis. Digital rectal examination showed decreased power, decreased tone, and intact sensation. Cervical magnetic resonance imaging (MRI) showed mild disc bulging in C3-C4 and C4-C5, and a diffuse disc bulging in $\mathrm{C5}-\mathrm{C} 6$, with an upward migration of the disc with spinal cord compression, narrowing both neural exit canals. Abnormal areas of T2 high signal intensity were seen in the spinal cord opposite to this level representing compressive myelopathy (-Fig. $\mathbf{1}$ ).

We performed an anterior cervical partial corpectomy of C5, discectomy of prolapsed C5-C6, and inserted a titanium mesh cage with plates and screws fusion. The subligamentous disc was found to be herniated and was removed with the calcified ligaments.

Upon surgery recovery, the patient was examined and found to have bilateral lower limb power weakness (0/5), and

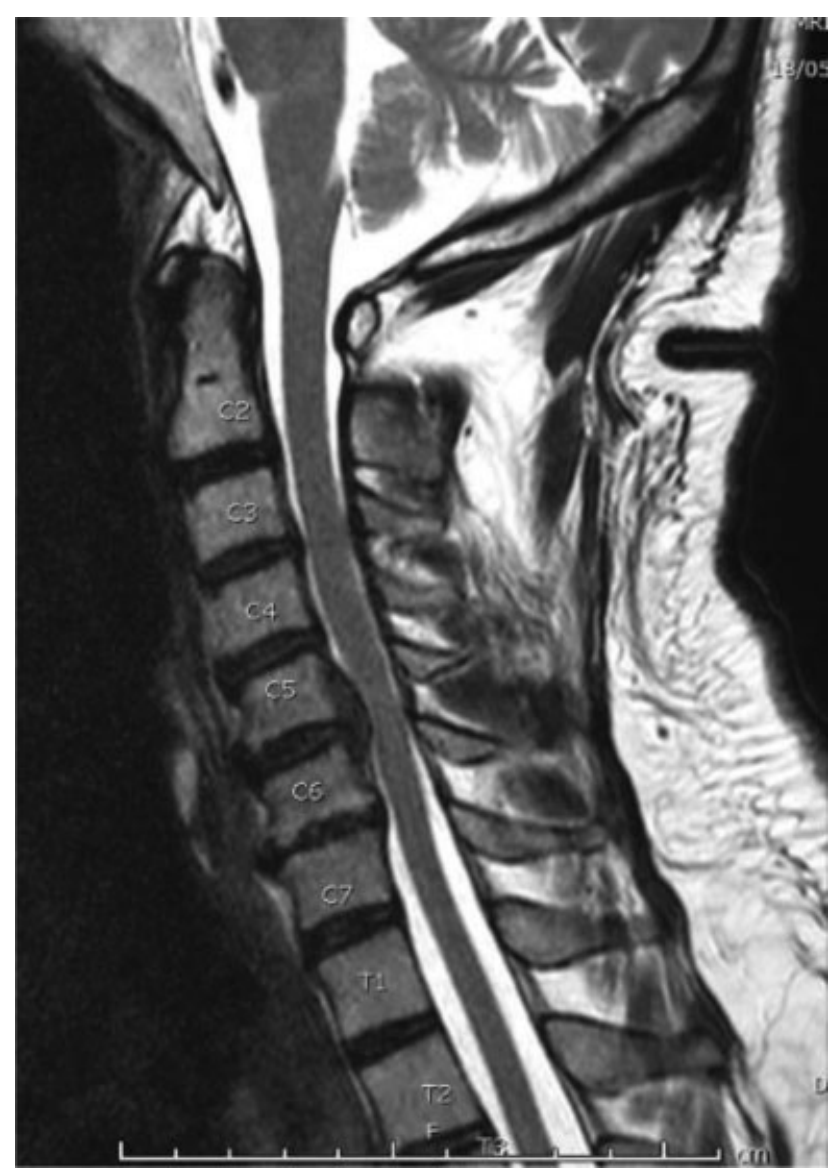

Fig. 1 Preoperative cervical magnetic resonance imaging shows mild disc bulging in $\mathrm{C} 3-\mathrm{C} 4$ and $\mathrm{C4}-\mathrm{C} 5$, and a diffuse disc bulging in $\mathrm{C} 6-\mathrm{C} 7$, with upward margination of the disc. upper limb power was $3 / 5$. Cervical and thoracic MRIs were performed on the operation day and showed posterior canal stenosis and severe compression with cord signal due to LF buckling (-Fig. 2). This led to planning an urgent surgery the next day, in which a posterior laminectomy procedure and canal decompression at the C5-C6 level with bone fusion were performed.

Postoperation, both upper and lower limbs strength were gradually recovered, and sphincters continence was regained within the following week after canal decompression. Afterward, the patient started intensive physiotherapy, which eventually enabled him to walk normally. Cervical MRI after 2 weeks demonstrated a decompressed spinal canal with no compression on the spinal cord and a satisfactory position of plates and screws (-Fig. $\mathbf{3}$ ).

\section{Discussion}

To our current knowledge, the current case presents one of the first cases of LF buckling as anterior cervical partial corpectomy and discectomy postsurgical complication in the literature. The patient underwent anterior cervical C5 partial corpectomy with C5-C6 discectomy and mesh cage insertion. Postsurgical examination showed bilateral motor defects in the upper and lower limbs. As a result, cervical MRI was done on the day of the operation, which confirmed

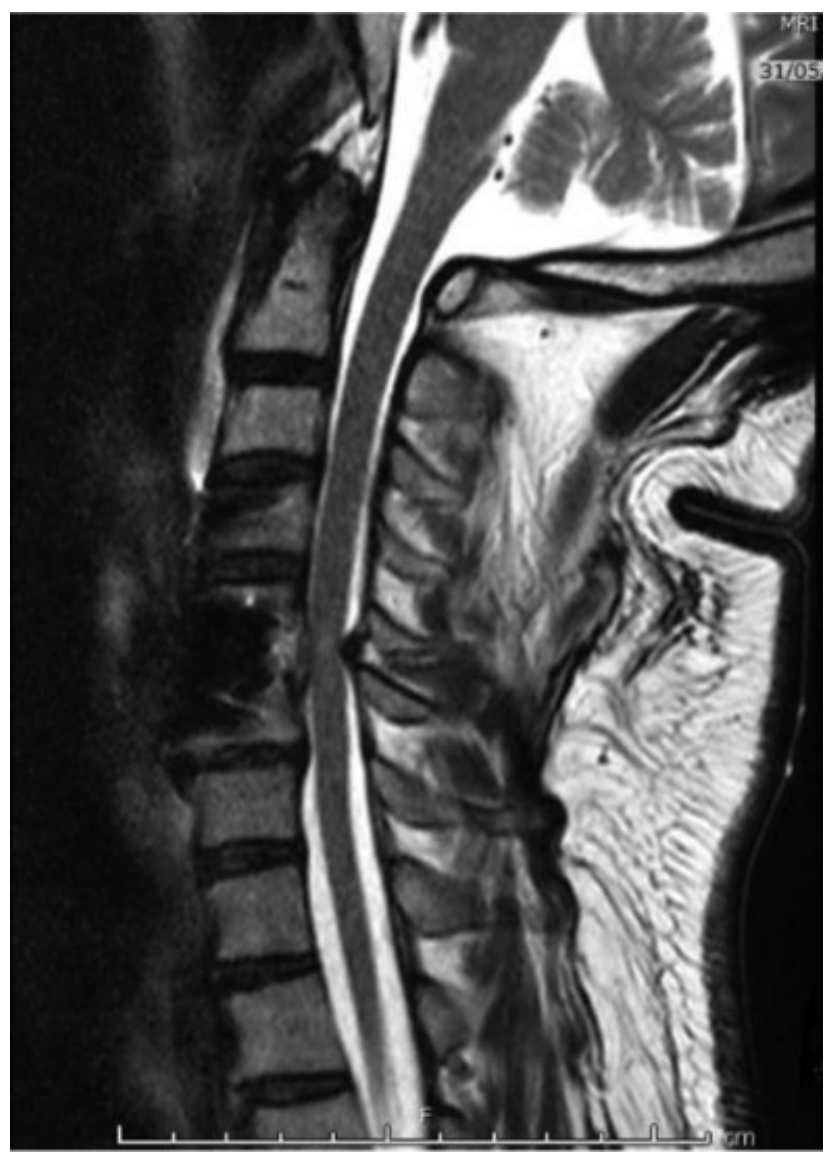

Fig. 2 Postoperative cervical magnetic resonance imaging shows posterior canal stenosis and severe compression with cord signal due to ligamentum flavum buckling. 


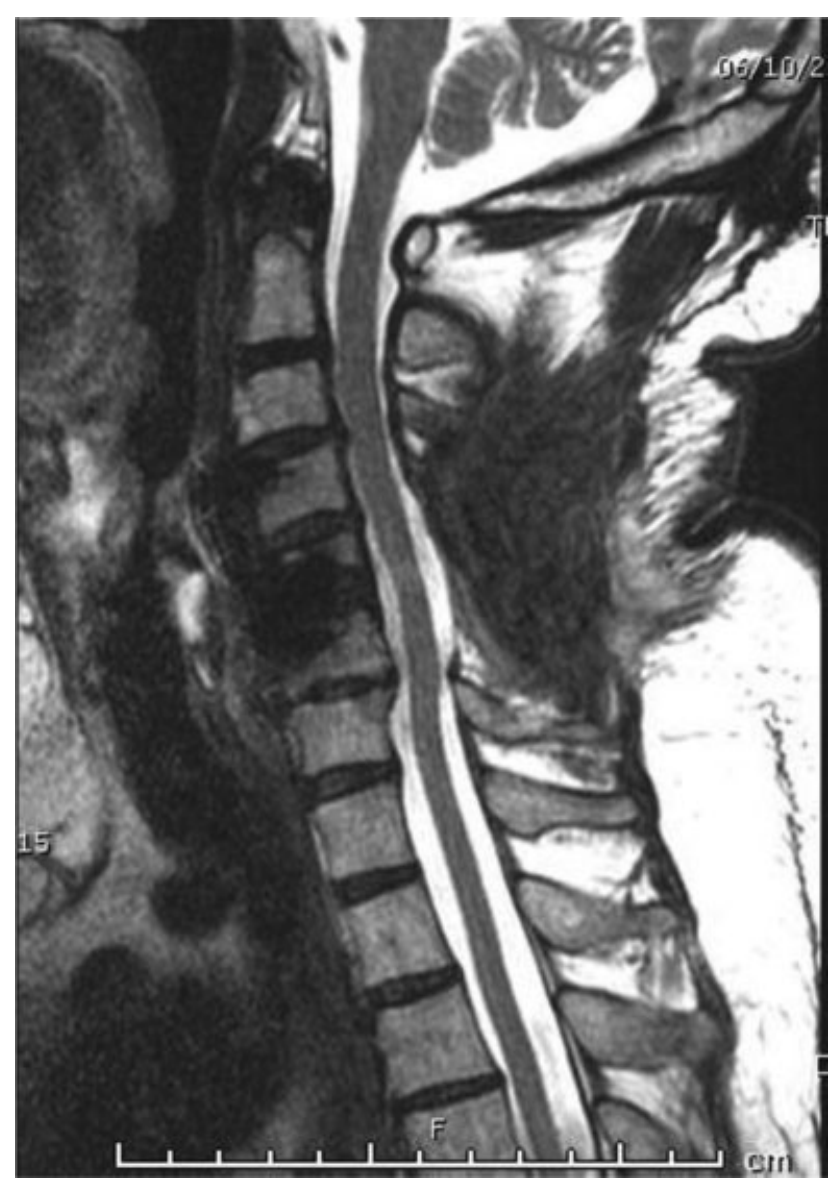

Fig. 3 Cervical magnetic resonance imaging after 2 weeks from the laminectomy procedure shows a decompressed spinal canal with no compression of the spinal cord and satisfactory positioning of the plates and screws.

posterior canal stenosis and severe compression with cord signal due to LF buckling.

A reported case was identified in similar settings. ${ }^{5}$ Yet, the authors reported carrying out the laminoplasty procedure after 13 months from the initial ACCF procedure. In our case, laminectomy was done the following day after the first procedure, this was mainly due to the postoperative profile of the patient, which was instantly confirmed to be LF buckling via MRI on the day of the initial procedure. This further emphasizes the necessity of immediate imaging following anterior cervical procedures to rule out any operative complications in case of any signs of neurological deterioration.

A suggested explanation for such complication includes LF hypertrophy, which occurs due to a decrease in the elastinto-collagen ratio. ${ }^{6}$ The elastin in the LF plays a critical role in preventing the LF from buckling during cervical extension. This role is compromised as a result of elastic fibers rupture during LF thickening. ${ }^{7}$ The effect of LF thickening is most prominent when accompanied by distance shortening between the adjacent vertebral arches in case of disc prolapse. Additionally, the increase of the lordotic curvature, as suggested by He L et al., plays a significant role in shortening the distance between the attachment points of the LF. ${ }^{5}$ Thus, considering the positioning of the patient during the surgery, in which hyper-extension of the cervical region is imposed, we believe this could potentially increase the risk of LF buckling. Besides buckling of the LF, patients could present with flavum hematomas, which are another possible cause of limb weakness that may occur spontaneously, due to trauma, or due to bleeding tendencies. ${ }^{8}$

Commonly used procedures in cervical spondylotic myelopathies are anterior cervical corpectomy and fusion (ACCF) as well as anterior cervical discectomy and fusion (ACDF), which may be favored over ACCF in single-level $\mathrm{CSM}^{9}$ In multi-level CSM, a meta-analysis compared both ACCF and ACDF in terms of surgical outcomes and complications, and it resulted in similar outcomes between both. However, fewer complications were observed in the ACDF arm; this may be owed to the shorter operation time that results in lower blood loss as well as enhanced sagittal balance, which eventually reduces axial symptoms. $^{10,11}$

Taghvaei et al. reported a patient that underwent ACDF surgery and experienced LF buckling following the initial surgery; the patient, then, underwent posterior decompression with C4-C6 laminectomies. ${ }^{12}$ This further indicates the role of hyperextension positioning in causing LF buckling, which is seen in both ACCF and ACDF, thus supporting our theory.

Preventative measures to avoid neurological deterioration associated with LF buckling include careful head handling and positioning during surgery to avoid unnecessary cervical hyperextension as well as the accuracy of cage measurements based on preoperative CT scans to avoid both over and underestimation of its height. In case of any sign of neurological complications postoperatively, an instant MRI should be performed since early diagnosis in such settings results in a better prognosis.

Few cases reported in the literature support our theory, which indicates that hyperextension during surgery could cause LF buckling. Further studies and cases are needed to investigate whether there are other possible contributing factors.

\section{Conclusion}

Spinal cord compression could present after anterior cervical corpectomy and discectomy due to LF buckling. Careful head handling and positioning during surgery could prevent such complication. Early detection via immediate MRI scan postsurgery following signs of neurological deterioration is warranted to provide better outcomes in similar settings. Laminectomy and canal decompression were found to be effective in managing LF buckling.

\section{Highlights and Learning Points}

- Neurological deterioration could present after anterior cervical corpectomy or discectomy with fusion due to LF buckling. 
- Immediate imaging after surgery is necessary in case the patient shows any signs of neurological decay for early detection and better management.

- Preventative measures include careful head handling and positioning during surgery to avoid hyperextension of the cervical region.

Patient Consent

The patient signed a consent form after being informed of all the details.

\section{Authors Contribution}

O. J.: designed the study, collected data, critically revised the draft, and read and approved the final manuscript.

S. J.: managed the literature searches and completed the final draft, besides reading and approving the final manuscript.

H. A.: managed the literature searches and data collection and wrote the first draft of the manuscript, besides reading and approving the final manuscript.

S. S.: managed the literature searches, wrote the first draft of the manuscript, read, and approved the final manuscript.

Funding

The authors received no funding.

\section{Conflict of Interests}

The authors declare no conflict of interests.

\section{References}

1 Klineberg E. Cervical spondylotic myelopathy: a review of the evidence. Orthop Clin North Am 2010;41(02):193-202
2 McCormick JR, Sama AJ, Schiller NC, Butler AJ, Donnally CJ III. Cervical Spondylotic Myelopathy: A Guide to Diagnosis and Management. J Am Board Fam Med 2020;33(02):303-313

3 Boakye M, Patil CG, Ho C, Lad SP. Cervical corpectomy: complications and outcomes. Neurosurgery 2008;63(04, Suppl 2):295-301, discussion 301-302

4 Puvanesarajah V, Jain A, Cancienne JM, et al. Complication and Reoperation Rates Following Surgical Management of Cervical Spondylotic Myelopathy in Medicare Beneficiaries. Spine 2017;42 (01):1-7

5 He L, Qian Y. Anterior cervical corpectomy and fusion : Spinal cord compression caused by buckled ligamentum flavum. Orthopade 2019;48(02):170-174

6 Okuda T, Fujimoto Y, Tanaka N, Ishida O, Baba I, Ochi M. Morphological changes of the ligamentum flavum as a cause of nerve root compression. Eur Spine J 2005;14(03):277-286

7 Kosaka H, Sairyo K, Biyani A, et al. Pathomechanism of loss of elasticity and hypertrophy of lumbar ligamentum flavum in elderly patients with lumbar spinal canal stenosis. Spine 2007;32(25):2805-2811

8 Wild F, Tuettenberg J, Grau A, Weis J, Krauss JK. Ligamentum flavum hematomas of the cervical and thoracic spine. Clin Neurol Neurosurg 2014;116:24-27

9 Banno F, Zreik J, Alvi MA, Goyal A, Freedman BA, Bydon M. Anterior Cervical Corpectomy and Fusion Versus Anterior Cervical Discectomy and Fusion for Treatment of Multilevel Cervical Spondylotic Myelopathy: Insights from a National Registry. World Neurosurg 2019;132:e852-e861

10 Zhang Y, Liu H, Yang H, Pi B. Anterior cervical corpectomy and fusion versus discectomy and fusion for the treatment of twolevel cervical spondylotic myelopathy: analysis of sagittal balance and axial symptoms. Int Orthop 2018;42(08):1877-1882

11 Wang T, Wang H, Liu S, An HD, Liu H, Ding WY. Anterior cervical discectomy and fusion versus anterior cervical corpectomy and fusion in multilevel cervical spondylotic myelopathy: A metaanalysis. Medicine (Baltimore) 2016;95(49):e5437. Doi: 10.1097/ MD.0000000000005437

12 Taghvaei M, Meybodi KT, Zeinalizadeh M. Ligamentum Flavum Buckling Causing Immediate Post-Operative Neurological Deterioration After an Anterior Cervical Discectomy: Case Report. Turk Neurosurg 2018;28(04):678-681 